\title{
AGATHOXYLON SANTACRUZENSE KLOSTER \& GNAEDINGER FROM THE LOWER-MIDDLE JURASSIC KOTA FORMATION, INDIA AND ITS PALEOENVIRONMENTAL IMPLICATIONS
}

\author{
CHOPPARAPU CHINNAPPA (1) \\ Department of Botany (PG), Andhra Loyola College, Vijayawada 520008, Andhra Pradesh, India. \\ chinnabsip@gmail.com \\ PAULINE SABINA KAVALI (D) \\ Birbal Sahni Institute of Palaeosciences, 53 University Road, Lucknow 226 007, Uttar Pradesh, India. \\ paulinesabina@gmail.com
}

\begin{abstract}
Agathoxylon santacruzense (Araucariaceae) is reported here from the Lower-Middle Jurassic Kota Formation of PranhitaGodavari Basin, India. The taxon was originally described from the Middle Jurassic sediments of La Matilde Formation, Santa Cruz Province, Argentina. The wood has low percentage of latewood, and abrupt transitions of early-latewood reflects periods of intense growth. The growth ring parameters indicate that the growth conditions were seasonal but mostly stressful, and in some periods presented an erratic interruption. These growth rings show close similarity to those of modern tropical to subtropical conifers growing in the southern hemisphere. These results are concurrent with the broad subtropical belt that existed in the Jurassic.
\end{abstract}

Keywords: Agathoxylon, Jurassic, palaeoenvironments, Kota Formation, India.

RESUMO - Agathoxylon santacruzense (Araucariaceae) é aqui descrita para a Formação Kota do Jurássico Inferior-Médio da Bacia de Pranhita-Godavari, Índia. O táxon foi originalmente descrito a partir do Jurássico Médio da Formação La Matilde, Província de Santa Cruz, Argentina. A madeira com baixo percentual de lenho tardio e transição abrupta de lenho tardio reflete períodos de intenso crescimento. Os parâmetros do anel de crescimento indicam que as condições de crescimento foram sazonais, mas principalmente estressantes e em alguns períodos apresentaram uma interrupção errática. Esses anéis de crescimento apresentam semelhanças mais próximas com os das coníferas tropicais atuais e subtropicais que crescem no hemisfério sul. Esses resultados são compatíveis com o amplo cinturão subtropical que existia no Jurássico.

Palavras-chave: Agathoxylon, Jurassic, paleoambientes, Formação Kota, Índia.

\section{INTRODUCTION}

The Kota Formation is a significant lithostratigraphic unit of the Upper Gondwana Group of the Pranhita-Godavari valley of India. The formation derives its name from the village Kota, situated on the east bank of the river PranhitaGodavari in the Chandrapur District, Maharashtra (Figure 1). It is well known for its rich fossil vertebrate fauna, which includes semionotid and pholidophorid fishes, ostracods, reptiles, sphenodontians, triconodonts, morganucodontids, and docodont mammalians (Parmar et al., 2013 and references therein). The formation preserved large sized silicified woods of conifers too (Mahabale, 1967; Biradar \& Mahabale, 1978; Prabhakar, 1986; Rajanikanth \& Sukh Dev, 1989; Muralidhara Rao, 1991; Vijaya \& Prasad, 2001; Chinnappa \& Rajanikanth, 2016, 2018).

The fossil woods from the Kota Formation are of special interest since they are one of the main sources of information regarding the fossil floras and are very abundant (Mahabale, 1967; Biradar \& Mahabale, 1978; Rajanikanth \& Sukh Dev, 1989; Muralidhara Rao, 1991; Chinnappa \& Rajanikanth, 2016). The fossil woods from the Kota Formation include Agathoxylon kotaense Chinnappa \& Rajanikanth, A. pranhitaensis (Rajanikanth \& Sukh-Dev) Chinnappa \& Rajanikanth, A. santalense (Sah \& Jain) Bose \& Maheshwari sensu Chinnappa \& Rajanikanth, Agathoxylon sp., Cupressinoxylon kotaense Rajanikanth \& Sukh-Dev, Ginkgoxylon dixii Biradhar \& Mahabale, Podocarpoxylon chandrapurense Rajanikanth \& Sukh-Dev, P. krauselii Rajanikanth \& Sukh-Dev, P. rajmahalense (Jain) Bose \& Maheshwari, Podocarpoxylon sp., Prototaxoxylon liassicum Muralidhar Rao, Taxaceoxylon sahnii Rajanikanth \& SukhDev, and Taxaceoxylon sp. The fossil leaves, spores, and pollen, however, are rather rare and poorly preserved, and include pteridophytes and gymnosperms (Prabhakar, 1986; Rajanikanth \& Sukh Dev, 1989; Vijaya \& Prasad, 2001). 


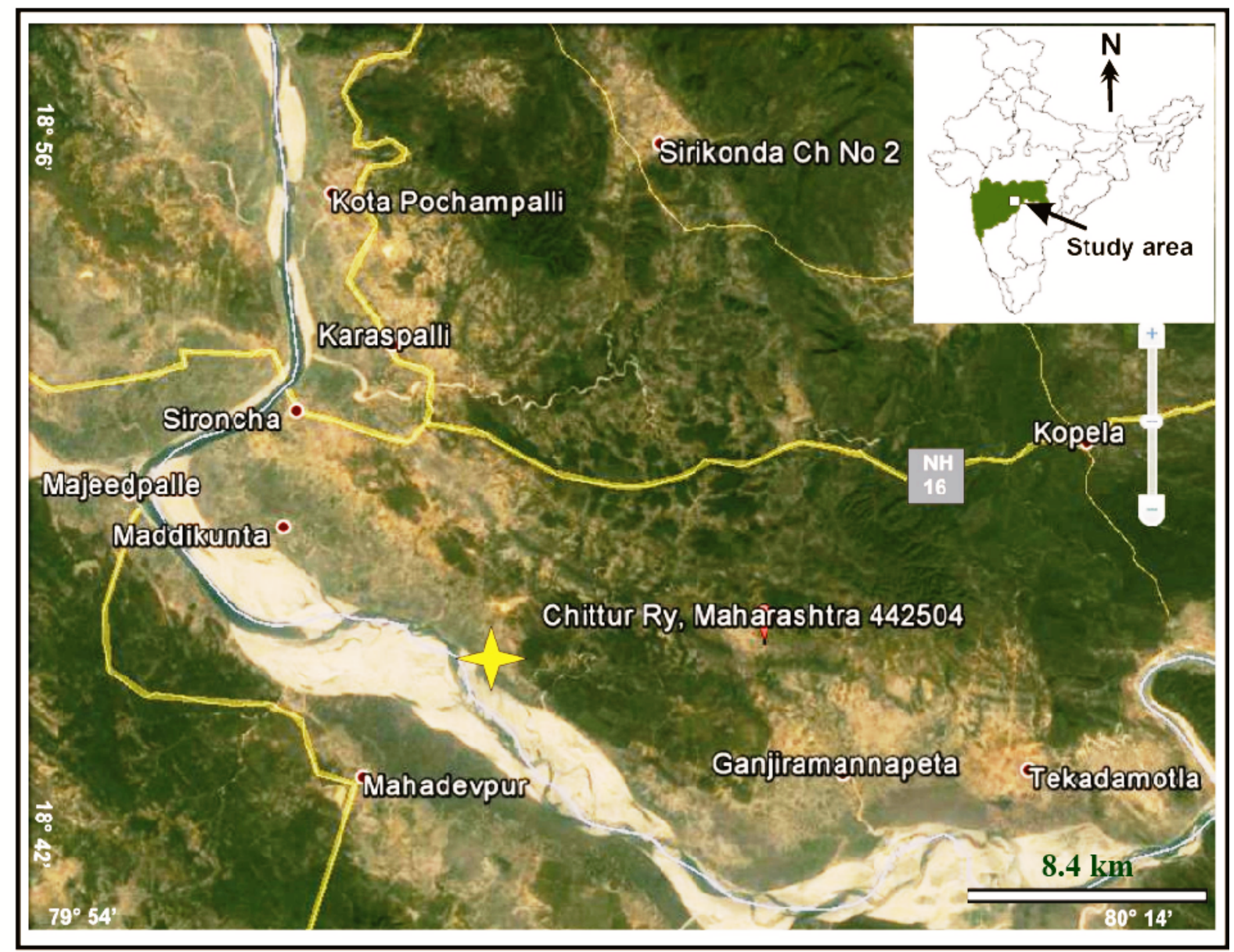

Figure 1. Locality map and aerial view of the fossil sites (indicated by a pentagonal symbol) near the Kota villages, State of Maharashtra, India.

The present study describes a coniferous wood of the species Agathoxylon santacruzense of Araucariaceae affinity from the Kota Formation and discusses its palaeoecological significance.

\section{GEOLOGICAL BACKGROUND AND AGE OF THE KOTA FORMATION}

The geology of the Kota Formation was studied by King (1881), Kutty (1969), Rudra (1982), Bhandhyopadhyay \& Rudra (1985), Raivarman et al. (1985), Kutty et al. (1987) and Lakshminarayana $(1994,2002)$. The formation is divided into Lower and Upper members by Rudra (1982). The Upper Member is characterized by a sequence, which includes: (i) light cream coloured, bedded limestone bands intercalated with clays and mudstones (these beds directly overlie the red clays of the Lower Member), (ii) red clays with ferruginous mudstones overlying the limestone zone, and (iii) siltstones and fine grained sandstones overlying the ferruginous mudstones (Table 1). The leafy fossils described from the Kota Formation were primarily known from the intercalated clays and mudstones in the lower horizons of the Upper Member and the woods were reported from the siltstones and fine-grained sandstones in the middle horizons of the Upper Member. The Kota Formation is positioned between the lower Maleri Formation, which is composed of red clays, lime pellets, and sandstones, and the upper Gangapur Formation, which is composed of white sandstones, buff siltstones, claystones and carbonaceous shales.

The age of the Kota Formation is variously dated, King (1881) assigned a Jurassic age to it and Krishnan (1968) a Liassic age. The early Jurassic age is primarily supported by the semionotid fish taxa (Jain, 1973, 1983), pholidophorid fish taxa (Yadagiri \& Prasad, 1977), and charophytes (Feist et al., 1991). However, Govindan (1975) and later Misra \& Satsangi (1979) proposed a Middle Jurassic age based on the ostracod assemblage. The Middle Jurassic to Early Cretaceous age was suggested by Prasad \& Manhas (2007) based on docodont mammalian, and by Vijaya \& Prasad (2001) based on the palynoflora. In recent review, Bandyopadhyay \& Roychowdhury (1996) proposed a Toarcian age (ca. 180 Ma, Gradstein et al., 1995, ICS, 2020) for these beds, while Datta et al. (2000) simply date them as Early Jurassic. The age assignments of the Kota Formation seem to be based on tenuous grounds, and the balance of evidence at present is in favor of a Middle Jurassic to Early Cretaceous age (Vijaya 
Table 1. Lithostratigraphy of Upper Gondwana sediments in the Pranhita-Godavari Basin (modified from Rudra, 1982).

\begin{tabular}{|c|c|c|c|}
\hline & Formation & Lithology & Age \\
\hline \multicolumn{4}{|c|}{ Deccan Traps } \\
\hline & Gangapur/Chikiala & Coarse ferruginous sandstone, pinkish grey-white mudstone and silty mudstone/shale & Early Cretaceous \\
\hline \multirow{4}{*}{$\begin{array}{l}\text { Upper } \\
\text { Gondwana }\end{array}$} & Kota & $\begin{array}{l}\text { Upper: Limestone bands intercalated with clays, mudstones, sandstone and siltstone } \\
\text { Lower: Sandstone with pebbles of banded chert }\end{array}$ & $\begin{array}{l}\text { ?Early-Middle } \\
\text { Jurassic }\end{array}$ \\
\hline & Maleri & Red clays, fine-medium sandstone and limestone & early Late Triassic \\
\hline & Bhimaram & Ferruginous/calcareous sandstone, minor red clays & late Middle Triassic \\
\hline & Yerrapalli & Red and violet clays with sandstone and limestone & early Middle Triassic \\
\hline
\end{tabular}

$\&$ Prasad, 2001). For the purpose of this paper, the Kota Formation is provisionally treated as Middle-Late Jurassic in age, with the understanding that this age assignment is open to modifications in the future.

\section{MATERIAL AND METHODS}

The fossil material studied here consists of three wood logs with secondary xylotomy characters only. They were collected from around the Kota and Chitur villages, Sironcha Taluk in Gadchiroli District of Maharastra State, India. The wood material prepared for this study was preserved as silicified surface material in a nala (small canal) section near Kota village. Preparation of the specimens was done by conventional rock thin section, ground to varying thicknesses to account for the unique preservation characteristics of each specimen. The sections were prepared in transverse (TS), radial longitudinal (RLS) and tangential longitudinal (TLS) planes. The sections were examined under an Olympus BH2 microscope with attached camera. The terminology used here mainly follows the IAWA Committee (2004), and identification of the fossil taxon is mainly based on the key to identify coniferous fossil-genera by Philippe \& Bamford (2008). The measurements were determined after measuring at least two dozen of cells in each case as followed by most recent xylotomists. The measurements represent minimum and maximum values with mean values in brackets. The slides (BSIP 16631, 16632, 16633, 16634, 16635, 16636, 16637, $16638,16639)$ are deposited at the repository of Birbal Sahni Institute of Palaeosciences, Lucknow, India.

\section{SYSTEMATIC PALEOBOTANY}

Family ARAUCARIACEAE

Agathoxylon Hartig, 1848

Type species. Agathoxylon cordaianum Hartig, 1848.

Agathoxylon santacruzense Kloster \& Gnaedinger, 2018

(Figures 2A-I)

Referred specimen. BSIP 16631, 16632, 16633, 16634, 16635, 16636, 16637, 16638, 16639.
Location. Near Kota village (7957'32'’E; 1854'50’'N), Sironcha Taluk, Gadchiroli District of Maharashtra State, India.

Horizon and age. Kota Formation, Middle-Late Jurassic. Description. Growth rings are distinct, $1-2 \mathrm{~mm}$ wide; the transition from the early wood to the late wood is abrupt (Figures 2A-B). Early wood tracheids are thin-walled, with broad lumen, rounded, rounded-square, rounded-rectangular or rounded-polygonal in transverse section. Tracheids range in size approximately from $88.5-(133.2)-182.4 \mu \mathrm{m}$ (vertical) by from 64.2-(116.2)-189.2 $\mu \mathrm{m}$ (horizontal). Late wood tracheids are thick-walled, rounded-rectangular, radially flattened in transverse section. They range in size approximately from 39.3-(77)-143 $\mu \mathrm{m}$ (vertical) by from $36-(78)-143 \mu \mathrm{m}$ (horizontal). Normal and traumatic resin canals are absent. The rays are separated from each other by 2-8 rows of tracheids; with an average of 4 rows.

In RLS, the wood type is araucarian (Figures $2 \mathrm{C}-\mathrm{F}$ ), i.e. with more than $90 \%$ of the pits contiguous, uni-biseriate, rarely triseriate radial pitting. Where pits are biseriate they are generally alternately to sub-oppositely arranged (Figures 2D, F). Pits are circular or hexagonal with circular apertures with an average diameter of $22 \mu \mathrm{m}$. The tracheid pits of the radial walls rang in size from $39-(56.7 \pm 1.76)-70.4 \mu \mathrm{m}$ (vertical) by from 34.6-(61 \pm 1.76$)-99 \mu \mathrm{m}$ (horizontal). The shape of the tracheid pits is mostly circular and they are almost always touching or rarely spaced by more than one pit diameter. The cross-field pits are araucarioid, 4-14 oculipores are present per field and are arranged in groups (Figure 2G). No ray tracheids were observed. There are no bars of Sanio or spiral thickenings in the tracheids.

In TLS rays are uniseriate (Figures $2 \mathrm{H}-\mathrm{I}$ ), and range in height from 32.6-(138.7 \pm 2.8$)-423 \mu \mathrm{m}$ and the ray height in number of cells is $1-(5 \pm 0.31)-12$. The ray cells are barrel shaped and variable in size, rang from 21.8-(49.5)-76.4 $\mu \mathrm{m}$ (vertical) by 29-(48.2)-72.7 $\mu \mathrm{m}$ (horizontal). Axial parenchyma is absent. Pitting of tracheid tangential walls is uniseriate and contiguous (Figure $2 \mathrm{H}$ ).

Remarks. According to the criteria of Bamford \& Philippe (2001), Philippe \& Bamford (2008), and Rößler et al. (2014), the genus Agathoxylon Hartig has nomenclatural priority over the genera Araucarioxylon and Dadoxylon; hence, the Kota specimens are assigned to Agathoxylon Hartig. Agathoxylon santacruzense was originally described from the Middle 

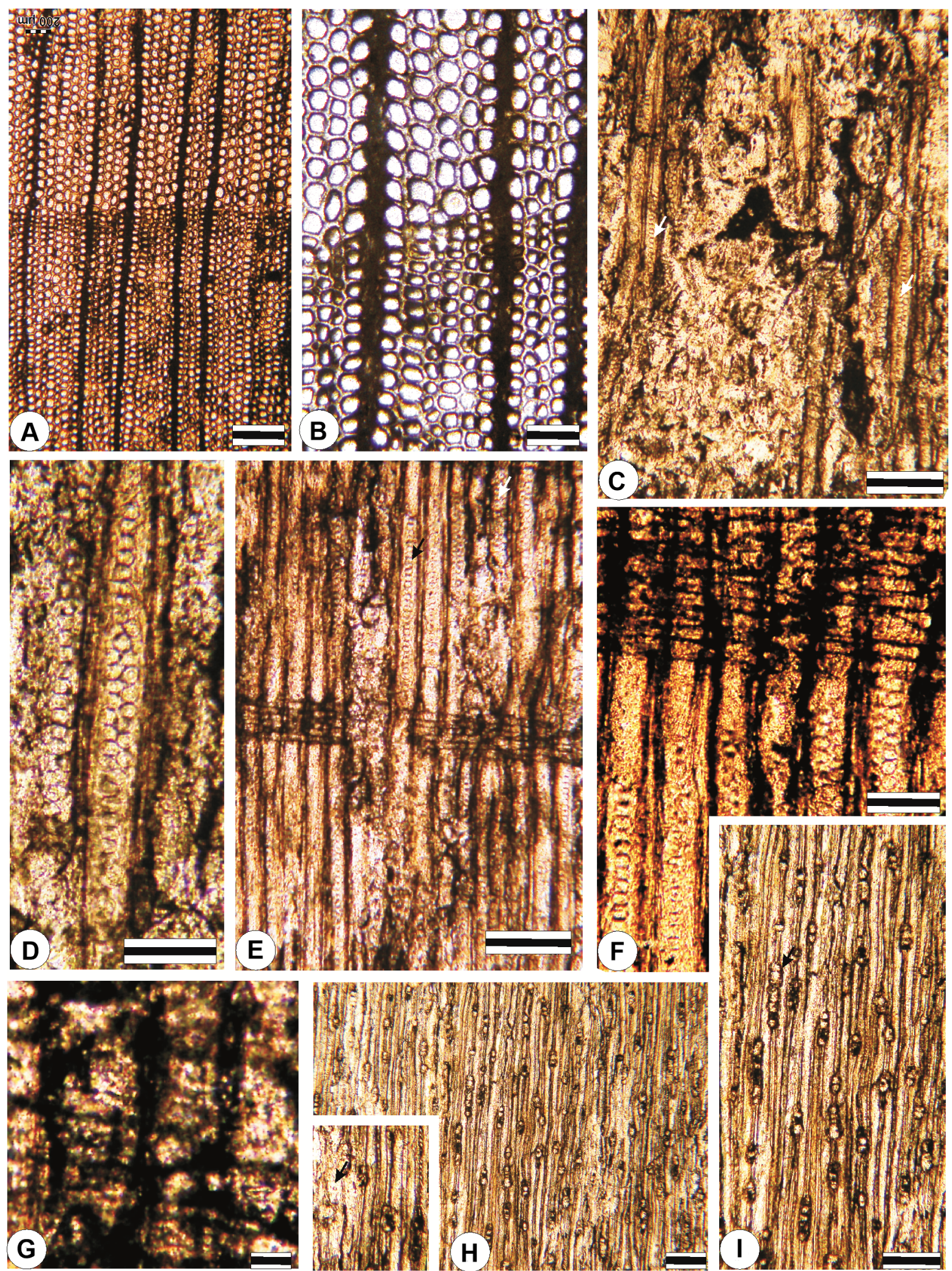

Figure 2. Agathoxylon santacruzense, BSIP 16631, 16632, 16633; A-B, transverse section showing growth ring and tracheid; C, radial section showing uni to tri-seriate bordered and hexagonal radial pitting (arrows); D, radial section showing uni and -biseriate bordered, hexagonal and alternate radial pitting (arrows); E, radial section showing uniseriate circular bordered pits (arrow); F, radial section showing uni-bi-seriate bordered circular and alternate radial pitting; $\mathbf{G}$, crossfield area with group of araucariod pits; $\mathbf{H}$, tangential section showing uniseriate ray cells (inset showing the tangential bordered pits; arrow); I, tangential section showing uniseriate bordered pits (arrows). Scale bars $=400 \mu \mathrm{m}$. 
Jurassic sediments of La Matilde Formation, Santa Cruz Province, Argentina (Kloster \& Gnaedinger, 2018). The description of the material in the present study agrees with that of $A$. santacruzense in many characters, such as number of cross-field pits, ray height in number, and type of bordered pits on radial walls. However, presence of tracheid pitting on the tangential walls of the tracheids is not reported for the material from the La Matilde Formation, Santa Cruz Province, Argentina. The feature serves as an important criterion in fossil material, however, it is difficult to separate the species by this character alone as they are influenced by the mode of preservation and ecological conditions.

Systematic affinities. Araucarian pitting on radial wall of tracheids with araucarioid cross-field is a diagnostic feature of the Agathoxylon woods. A similar combination of characters is also found in other genera such as Prototaxoxylon Kräusel \& Dolianiti (1958), and Simplicioxylon Andreanszky (1952). However, the presence of spiral thickenings in Prototaxoxylon and an oblique end wall of ray cells in Simplicioxylon help in distinguishing these two genera from Agathoxylon. Alternate and subopposite radial intertracheary pitting and cupressoid crossfield pitting is also characteristic of araucariaceous fossil wood and wood of Brachyoxylon Hollick \& Jeffrey (1909). However, Brachyoxylon includes woods with mixed radial pitting.

The present wood is characterized by araucarian radial pitting and araucarioid cross-field, but no spiral thickenings or oblique end wall of ray cells, thus the specimens show greater similarity to araucariaceous woods than to Prototaxoxylon, Simplicioxylon and Brachyoxylon. Consequently, the specimens are assigned to the xylotype Agathoxylon (Philippe \& Bamford, 2008).

\section{DISCUSSION AND CONCLUSIONS}

\section{Stratigraphic and Palaeoecological significance}

The precise age of the Kota Formation has long been subject of scientific debate. This is primarily because the sediments from this formation have not yielded any biostratigraphically significant index fossils. As no datable magmatic rocks occur above, below or intercalated with the formation, no radiometric dating is available. The Early Jurassic to the Early Cretaceous age was suggested based on faunal and floral evidence (Vijaya \& Prasad, 2001; Chinnappa et al., 2018). However, the recent discovery of fossil fauna strongly suggested Lower to Middle age connotation such as the Early to Middle Jurassic (Parmar et al., 2013). The present finding of fossil wood belonging to Agathoxylon santacruzense, species originally described from the Middle Jurassic La Matilde Formation, Santa Cruz Province, Argentina (Kloster \& Gnaedinger, 2018) also favors the restricted age connotation. However, it is possible that the age considered here for the Kota Formation would be subjected to modification as we get more and more information in the future.

The Agathoxylon santacruzense described here show distinct growth rings and they are of type A or B as classified

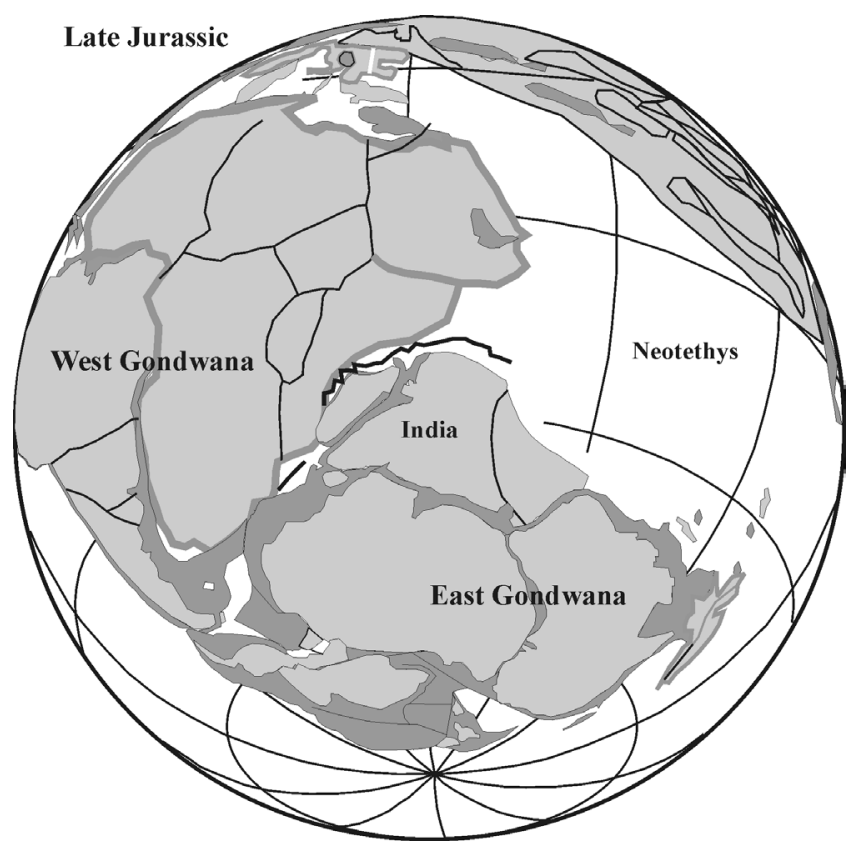

Figure 3. Late Jurassic paleogeographic map showing the position of the Indian sub-continent (after Chatterjee et al., 2013).

by Creber \& Chaloner (1984) and illustrated by Brison et al. (2001) reflecting paleoclimate of this area did have marked seasons during the tree growth (Fritts, 1976; Creber \& Chaloner, 1985; Francis \& Poole, 2002; Yang et al., 2013). The other wood taxa Cupressinoxylon, Ginkgoxylon, Podocarpoxylon, Prototaxoxylon and Taxaceoxylon with distinct growth rings reported from the Kota Formation also favors such interpretations (Chinnappa \& Rajanikanth, 2018). Nevertheless, the growth rings of these woods differ from the rings of temperate woods such as Pinus sylvestris, and show a close similarity to the growth rings of modern tropical to subtropical conifers growing in the southern hemisphere.

During the Jurassic the Indian subcontinent was in the southern Subtropical Arid Belt of $30-32^{\circ} \mathrm{S}$ (Figure 3; Chatterjee et al., 2013). The Jurassic climate is considered as more equable than that of present day, with tropicalsubtropical conditions. The Jurassic world was one in which low latitudes were seasonally dry (summer wet or subtropical), succeeded polewards in both hemispheres by desert, seasonally dry (winter wet), warm temperate and cool temperate biomes (Rees et al., 2000). The weakly defined growth rings and poorly presented growth interruptions are typical of woods from warm subtropical climates, and a seasonally dry ecotone is evidenced by the presence of cupressoid conifers (Rajanikanth \& Sukh Dev, 1989).

The prevailing climatic conditions in the Kota Formation of the Pranhita-Godavari Basin appear as a persistence of the subtropical climate that characterized the Jurassic deposits of the other basins (Rees et al., 2000; Prachiti et al., 2011). This climatic interpretation is also supported by the micro- and macro- flora characterised by the presence of conifers related to Araucariaceae and Cheirolepidiaceae (Mahabale, 1967; Biradar \& Mahabale, 1978; Prabhakar, 1986; Rajanikanth \& Sukh Dev, 1989; Muralidhara Rao, 1991; Vijaya \& Prasad, 
2001; Chinnappa \& Rajanikanth, 2016, 2018). These data also indicate that the plants were growing in subtropical environments with seasonal drought (Rajanikanth \& SukhDev, 1989). Additionally, the petrological study done by Prachiti et al. (2011) favors such interpretation too.

\section{ACKNOWLEDGEMENTS}

The authors are grateful to the V. Prasad, Director, Birbal Sahni Institute of Palaeobotany, Lucknow, India for their support and encouragement. We acknowledge our sincere thanks to the anonymous reviewers for their constructive suggestions.

\section{REFERENCES}

Andreanszky, G. 1952. Der versteinerte Wald von Mikofalva und einige andere verkieselte Baumstamme aus Ungarn. Annales biologicae Universitatum Hungariae, 1:15-24.

Bamford, M. \& Philippe, M. 2001. Gondwanan Jurassic-Early Cretaceous homoxylous woods: a nomenclatural revision of the genera with taxonomical notes. Review of Palaeobotany and Palynology, 113:287-297. doi:10.1016/S0034-6667(00)00065-8

Bandyopadhyay, S. \& Roychowdhury, T.K. 1996. Beginning of the continental Jurassic in India: a palaeontological approach. Museum of Northern Arizona Bulletin, 60:371-378.

Bhandhyopadhyay, S. \& Rudra, D.K. 1985. Upper Gondwana stratigraphy, north of the Pranhita-Godavari confluence, southern India. Journal of the Geological Society of India, 26:261-266.

Biradar, N.V. \& Mahabale, T.S. 1978. Occurrence of Ginkgo like wood in east coast Gondwanas of India. Recent Research in Geology, 5:146-153.

Brison, A.L.; Philippe, M. \& Thevenard, F. 2001. Are Mesozoic wood growth rings climate induced? Palaeobiology, 27:531-538. doi:10.1666/0094-8373(2001)027<0531:AMWGRC>2.0.CO;2

Chatterjee, S.; Goswami, A. \& Scotese, C.R. 2013. The longest voyage: tectonic, magmatic, and paleoclimatic evolution of the Indian plate during its northward flight from Gondwana to Asia. Gondwana Research, 23:238-267. doi:10.1016/j. gr.2012.07.001

Chinnappa, C. \& Rajanikanth, A. 2016. A new species of Circoporoxylon from Kota formation (Jurassic), PranhitaGodavari Basin, India and palaeobiogeography of the genus. Ameghiniana, 53:675-684. doi:10.5710/AMGH.19.07.2016.2954

Chinnappa, C. \& Rajanikanth, A. 2018. Mesozoic woods from India: nomenclature review and palaeoclimatic implications. Palaeoworld, 27:211-225. doi:10.1016/j.palwor.2017.12.004

Chinnappa, C.H.; Kavali, P.S. \& Rajanikanth, A. 2019. Protaxodioxylon from the Late Jurassic to Early Cretaceous Kota Formation, Pranhita-Godavari Basin, India. Paleontological Journal, 53:12065-1215. doi:10.1134/s0031030119110029

Creber, G.T. \& Chaloner, W.G. 1984. Influence of environmental factors on the wood structure of living and fossil trees. Botanical Review, 4:357-448. doi:10.1007/BF02862630

Creber, G.T. \& Chaloner, W.G. 1985. Tree growth in the Mesozoic and Early Tertiary and the reconstruction of palaeoclimate. Palaeogeography, Palaeoclimatology, Palaeoecology, 52:3560. doi:10.1016/0031-0182(85)90030-6
Datta, P.M.; Manna, P.; Ghosh, S.C. \& Das, D.P. The first Jurassic turtle from India. Palaeontology, 43:99-109. doi:10.1111/14754983.00120

Feist, M.; Bhatia, S.B. \& Yadagiri, P. 1991. On the oldest representative of the family Characeae and its relationship with the Porocharaceae. Bulletin de la Société Botanique de France, 138:25-32. doi:10.1080/01811789.1991.10827039

Francis, J.E. \& Poole, I. 2002. Cretaceous and early Tertiary climates of Antarctica: evidence from fossil wood. Palaeogeography, Palaeoclimatology, Palaeoecology, 182:47-64. doi:10.1016/ S0031-0182(01)00452-7

Fritts, H.C. 1976. Tree rings and climate. London, Academic Press, $567 \mathrm{p}$.

Govindan, A. 1975. Jurassic freshwater ostracods from the Kota limestones of India. Palaeontology, 18:207-216.

Gradstein, F.M.; Agterberg, F.P.; Ogg, J.G.; Hardenbol, J.; Van Veen, P.; Thierry, J. \& Huang, Z. 1995. A Triassic, Jurassic, and Cretaceous time scale. In: W.A. Berggren; D.V. Kent; M-P. Aubry \& J. Hardenbol (eds.) Geochronology, time scales and global stratigraphic correlation, Tulsa, SEPM (Special Publication 54). doi:10.2110/pec.95.04.

Hartig, A. 1848. Beiträge zur Geschichte der Pflanzen und zur Kenntnis der norddeutschen Braunkohlen-Flora. Botanische Zeitung, 6:185-190.

Hollick, A. \& Jeffrey, E.C. 1909. Studies of coniferous cretaceous remains from Kreischerville, New York. Memoirs of the New York Botanical Garden, 3: 1-137. doi:10.5962/bhl.title.44790

IAWA Committe, 2004. List of microscopic features for softwood identification. IAWA journal, 25:1-70.

ICS - International Commission on Stratigraphy. 2020. International Chronostratigraphic Chart v. 2020/03. In: https://stratigraphy. org/ICSchart/ChronostratChart2020-03.pdf. Access in: 30 nov 2020.

Jain, S.L. 1973. New specimens Lower Jurassic holostean fishes from India. Palaeontology, 16:149-177.

Jain, S.L. 1983. A review of the genus Lepidotes (Actinopterygii: Semionotiformes) with special reference to the species from Kota Formation (Lower Jurassic), India. Journal of the Palaeontological Society of India, 28:7-42.

King, W. 1881. The geology of the Pranhita-Godavari Valley. Memoirs of the Geological Survey of India, 18:1-151.

Kloster, A.C. \& Gnaedinger, S. 2018. Coniferous wood of Agathoxylon from the La Matilde Formation, (Middle Jurassic), Santa Cruz, Argentina. Journal of Palaeontology, 92:1-22. doi:10.1017/jpa.2017.145

Kräusel, R. \& Dolianiti, E. 1958. Gymnospermhölzer aus dem Paläozoikum Brasiliens. Palaeontographica B, 104:115-137.

Krishnan, M.S. 1968. Geology of India and Burma. 5th ed., Higginbothams, Madras.

Kutty, T.S. 1969. Some contribution to the stratigraphy of the Upper Gondwana formations of the Pranhita-Godavari Valley, central India. Journal of the Geological Society of India, 10:33-48.

Kutty, T.S.; Jain, S.L. \& Roy Chowdhury, T. 1987. Gondwana sequence of the northern Pranhita-Godavri Valley: its stratigraphy and Vertebrate faunas. Palaeobotanist, 36:214-229.

Lakshminarayana, G. 1994. Stratigraphy and structural framework of the Gondwana sediments in the Pranhita-Godavari Valley, Andhra Pradesh. Gondwana Nine, 1:311-330.

Lakshminarayana, G. 2002. Evolution in Basin fill style during the Mesozoic Gondwana continental breakup in the Godavari Triple Junction, SE India. Gondwana Research, 5:227-244. doi:10.1016/S1342-937X(05)70906-0 
Mahabale, T.S. 1967. Mesozoic floras of India: the Kota-Maleri stage. Palaeobotanist, 15:308-312.

Misra, R.S. \& Satsangi, P.P. 1979. Ostracods from Kota Formation. Proceedings of the Colloquium on Micropalaeontology and Stratigraphy. Geological survey of India Miscellaneous Publication, 45:73-80.

Muralidhara Rao, G. 1991. On a silicified wood from the Kota Formation (Liassic) of the Pranhita-Godavari Basin. Swamy Journal of Botany, 8:107-112.

Parmar, V.; Prasad, G.V. \& Kumar, D. 2013. The first multituberculate mammal from India. Naturwissenschaften, 100:515-523. doi:10.1007/s00114-013-1047-0

Philippe, M. \& Bamford, M.K. 2008. A key to morphogenera used for Mesozoic conifer like woods. Review of palaeobotany and palynology, 148:184-207. doi: 10.1016/j.revpalbo.2007.09.004

Prabhakar, M. 1986. Palynological evidences and its significance for the Kota Formation in the Pranhita-Godavari basin. In: INDIAN COLLOQUIUM ON MICROPALAEONTOLOGY AND STRATIGRAPHY, 12, 1986. Proceedings, Delhi, p. 59-65.

Prachiti, P.K.; Manikyamba, C.; Singh, P.K.; Balaram, V.; Lakshminarayana, G.; Raju, K. \& Arora, M. 2011. Geochemical systematics and precious metal content of the sedimentary horizons of Lower Gondwanas from the Sattupalli coal field, Godavari Valley, India. International Journal of Coal Geology, 88:83-100. doi:10.1016/j.coal.2011.08.005Get

Prasad, G.V.R. \& Manhas, B.K. 2007. A new docodont mammal from the Jurassic Kota Formation of India. Palaeontologia Electronica, 10:1-11.

Raivarman, V.; Rao, M.R. \& Pal, D. 1985. Stratigraphy and structure of the Pranhita-Godavari Graben. Petroleum Asia Journal, 8:174-190.
Rajanikanth, A. \& Sukh-Dev, A. 1989. The Kota Formation: fossil flora and stratigraphy. Geophytology, 19:52-64.

Rees, P.M.; Ziegler, A.M.; Valdes, P.J.; Huber, B.T.; MacLeod, K.G. \& Wing, S.L. 2000. Jurassic phytogeography and climates: new data and model comparisons. In: B.T. Huber; K.G. Macleod \& S.L. Wing (eds.) Warm climates in earth history, Cambridge University Press, p. 297-318.

Rößler, R.; Philippe, M.; van Konijnenburg-van Cittert, J.H.A.; McLoughlin, S.; Sakala, J.; Zijlstra, G.; Annamraju, R.; Ash, S.; Baas, P.; Bamford, M. et al. 2014. Which name(s) should be used for Araucaria-like fossil wood?-Results of a poll. Taxon, 63:177-184. doi:10.12705/631.7

Rudra, D.K. 1982. Upper Gondwana stratigraphy and sedimentation in the Pranhita-Godavari Valley, India. Quaternary Journal of the Geological, Mining and Metallurgical Society of India, 54:56-79.

Vijaya, X. \& Prasad, G.V.R. 2001. Age of the Kota Formation, Pranhita Godavari Valley, India. A palynological approach. Journal of the Palaeontological Society of India, 46:77-93.

Yadagiri, P. \& Prasad, K.N. 1977. On the discovery of new pholidophorus fishes from Kota Formation, Adilabad District, Andhra Pradesh. Journal of the Geological Society of India, 18:436-444.

Yang, X.J.; Wang, Y.D. \& Zhang, W. 2013. Occurrences of Early Cretaceous fossil woods in China: implications for paleoclimates. Palaeogeography, Palaeoclimatology, Palaeoecology, 385:213220. doi:10.1016/j.palaeo.2013.05.019

Received in 13 January, 2020; accepted in 21 August, 2020. 